\title{
An Application of Distributed Hydrological Model, YHyM/BTOPMC to Gin Ganga Watershed, Sri Lanka
}

\author{
T. N. Wickramaarachchi, H. Ishidaira and T. M. N. Wijayaratna
}

\begin{abstract}
Modelling approach is a useful tool which provides information on spatial distribution of basin hydrologic components. In that context distributed hydrological models play a vital role in efficient planning and managing water resources systems. But their applications are partly limited due to the requirement of large amount of data which are not always available and difficulties in obtaining such data due to bureaucratic constraints. Global public domain data sets have become increasingly available on the internet and it is appropriate to make use of such data which can often be supplemented for ground-based data. The objective of this study is to investigate the applicability of the distributed hydrological model, YHyM/BTOPMC to simulate the major hydrological characteristics in Gin ganga watershed utilizing the global data sets readily available in public domain along with the local available rainfall and discharge data. Gin ganga is a river which is one of the main sources of water supply to the southern region of Sri Lanka. It's catchment entirely lies within the wet zone of the country and frequently subjected to flooding during the rainy seasons. Hence, it is vital to comprehend the hydrology of the watershed in order to gain knowledge on current and future hydrological conditions. In the study, YHyM/BTOPMC model performance was evaluated by the Nash-Sutcliffe Efficiency (E) and the volume ratio of simulated discharge to observed discharge (Vr). The results show that the overall hydrological behaviour of the Gin ganga watershed is adequately simulated by the model. Further the results are discussed in the context of how the model simulation results replicate the temporal variation of basin hydrological characteristics such as ground water saturation deficit, soil moisture states, base flow etc.
\end{abstract}

Keywords: Watershed modelling, global public domain data, hydrological characteristics

\section{Introduction}

Hydrologic modelling is now well recognized as a powerful technique in land and water resources planning, development and management. Hydrological models can be classified according to the process description and spatial representation. According to the process description, models can be classified into three categories: metric, conceptual and physically-based models. According to the spatial representation, hydrological models are either lumped or distributed. Choice of a suitable model structure relies heavily on the function that the model needs to serve. Distributed models in hydrology are usually physically based in that they are defined in terms of theoretically acceptable continuum equations. Distributed hydrological models can fulfil the necessities of describing basin heterogeneity, and assessing the impact of natural and human induced changes. Furthermore they enable researchers to take advantage of currently available satellite observations, the quality of which is rapidly increasing (Virtual Academy, 2010). The University of Yamanashi Distributed Hydrological Model with Block-wise use of
TOPMODEL and Muskingum-Cunge method (YHyM/BTOPMC) was developed to cover most of the requirements for modelling hydrological responses of a basin, and has already been successfully applied to many catchments around the world. Most of the parameters to be identified in the YHyM/BTOPMC are related to physical basin features of land cover and soil.

The objective of this study is to investigate the applicability of the YHyM/BTOPMC to simulate the major hydrological characteristics in Gin ganga watershed utilizing the global data sets readily available in public domain along with the local available rainfall and discharge data.

Eng. (Mrs) T. N. Wickramaarachchi, B.Sc. Eng(Hons) (Moratuwa), MPhil (Moratuwa), AMIE(Sri Lanka), Senior Lecturer, Department of Civil \& Env. Engineering, University of Ruhuna. (Currently reading for a $\mathrm{PhD}$ )

Eng. (Dr) H. Ishidaira, B.Sc. Eng(Nagaoka), M.Eng (Nagaoka), D.Eng (Nagaoka), Associate Professor, Interdis. Graduate School of Medicine and Engineering, University of Yamanashi, Japan.

Eng. (Dr) T. M. N. Wijayaratna, B.Sc. Eng(Hons) (Moratuwa), M.Eng (AIT), D.Eng (Yokohama), C.Eng, MIE(Sri Lanka), Senior Lecturer, Department of Civil \& Env. Eng., University of Ruhuna. 


\section{Study Area}

Gin river is one of the main sources of water supply to the southern region of Sri Lanka. It is located roughly between longitudes $80^{\circ} 08^{\prime \prime} \mathrm{E}$ and $80^{\circ} 40^{\prime \prime} \mathrm{E}$, and latitudes $6^{\circ} 04^{\prime \prime} \mathrm{N}$ and $6^{\circ} 30^{\prime \prime} \mathrm{N}$. Gin river having a catchment area of about $932 \mathrm{~km}^{2}$ includes Galle (83\% of the basin area), Matara $(9 \%$ of the basin area), Rathnapura (7\% of the basin area), and Kalutara (1\% of the basin area) administrative districts. The river originates from the Gongala mountains in Deniyaya having an elevation of over $1300 \mathrm{~m}$ and flows to the Indian Ocean in Ginthota area of Galle District. Rainfall pattern in the catchment is of bi-modal, falling between May and September (south west monsoon, which is the major rainfall event), and again between November and February (north east monsoon) followed by the inter-monsoon rains during the remaining months of the year. Rainfall varies with altitude with mean annual rainfall above $3500 \mathrm{~mm}$ in the upper reaches to less than $2500 \mathrm{~mm}$ in the lower reaches of the catchment. River Gin annually discharges about 1268 million cubic meters to sea (National Atlas, 2007). Average temperature in the catchment varies from $24^{\circ} \mathrm{C}$ to $32^{\circ} \mathrm{C}$ with high humidity levels and the dominant soil texture is sandy clay loam. The watershed of the river is rather a natural catchment in Sri Lanka which entirely lies within the wet zone of the country and having a natural rainforest covering considerable area in its upper catchment.

Since most of the low-lying areas in the Galle District are frequently subjected to flooding during the rainy seasons, problem of Gin river flooding is considered as leading to environmental hazard of the district. Due to rapidly growing population and development activities in some parts of the catchment, demand for water is likely to increase. Galle is the capital city in southern Sri Lanka and the city's main pipe -borne water supply system depends on the water resources in Gin catchment. Hence, it is vital to comprehend the hydrology of the catchment in order to gain knowledge on current and future hydrological conditions. Figure 1 shows the location of Gin ganga watershed.

\section{Hydrological Simulation}

\subsection{Model Description}

The University of Yamanashi Distributed Hydrological Model (YHyM) with Block-wise use of TOPMODEL and Muskingum-Cunge method (BTOPMC) is a grid-based distributed hydrological model developed at the University of Yamanashi, Japan [Ishidaira et al (2000) and Takeuchi et al (1999 and 2008)]. Enabling easy and reliable application, many data which are required to run the model are available freely in the global public domain. The model is available for training at the University of Yamanashi Virtual Academy http://www.coe. yamanashi.ac.jp/

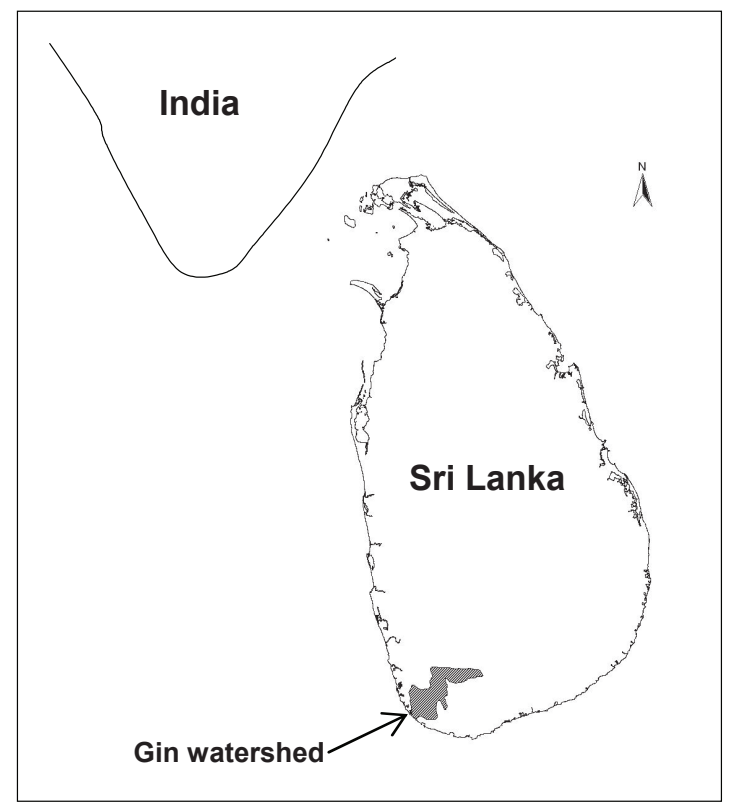

Figure 1 - Location of Gin ganga watershed

In the $\mathrm{YHyM}$, runoff is generated based on the TOPMODEL concept (Beven and Kirkby, 1979) and flow routing is carried out using the Muskingum Cunge method (Cunge, 1969 and Ao et al., 2003a,b). Core hydrological module included in the BTOPMC includes Topographic model, Runoff generation, Flow routing, and parameter identification.

The main features of Block-wise TOPMODEL (BTOP) include sub division of basin into a number of blocks, each of which may consist of several hillslopes and sub-surface water is assumed to be shared within each hillslope but not between blocks. After the holding capacity has been filled, the effective rainfall over a block discharges either as overland flow from each grid cell that is saturated, or as sub-surface flow to a local stream segment positioned in each grid cell in the block, or both. The hydrological processes in a grid cell in the BTOP model are illustrated in Figure 2 (Takeuchi et al., 2008).

The watershed is described by drainage networks extracted from digital elevation models (DEMs), in which all pits are filled with 
calculated small elevation increments (Ao et al.,2001, 2003b). The topographic index $\gamma_{i}$ for the $i^{\text {th }}$ grid cell is calculated using equation (1).

$\gamma_{i}=\ln \left(\alpha_{i} / \tan \beta_{i}\right)$

where, $\alpha_{i}$ is the drainage area per unit length of contour, $\tan \beta_{i}$ denotes the slope of grid cell, $i$.

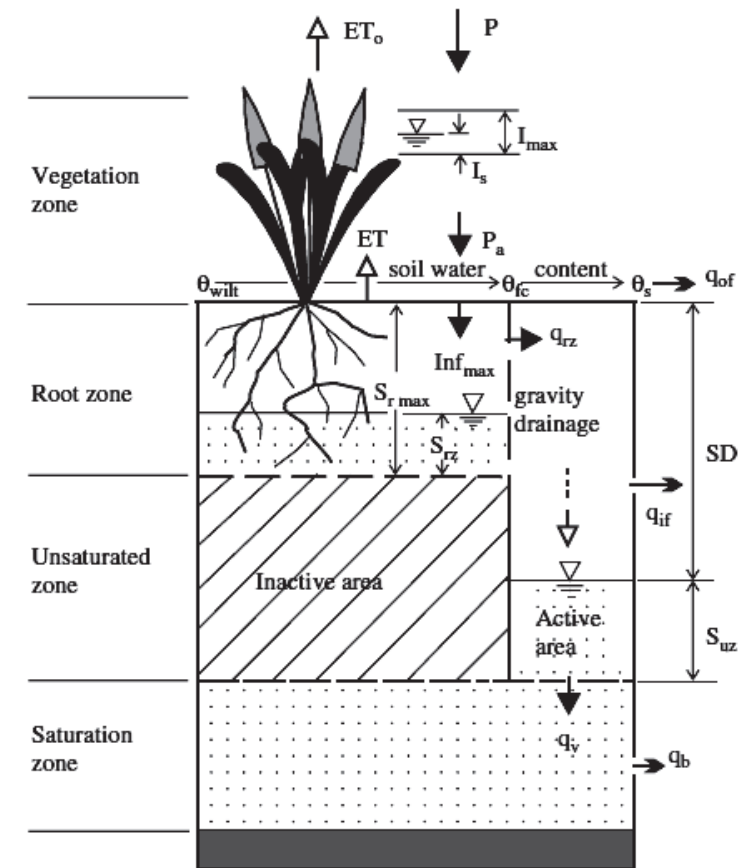

Figure 2 - Runoff generation in a grid cell in the BTOP model (the vertical profile).

In this diagram, $P$ is the gross rainfall, $E T_{0}$ is the interception evaporation, $I_{\max }$ is the interception storage capacity, $I$ is the interception state, $\operatorname{In} f_{\max }$ is the infiltration capacity, $P_{a}$ is the net rainfall on the land surface, ET is the actual evapotranspiration, $S_{r \max }$ is the storage capacity of the root zone, $S_{r z}$ is the soil moisture state in root zone, $S D$ is soil moisture deficit in unsaturated zone, $S_{u z}$ is the soil moisture state in unsaturated zone, $q_{o f}$ is the overland runoff, $q_{\text {if }}$ is the saturation excess runoff, $q_{v}$ is the groundwater recharge, and $q_{b}$ is groundwater release. $\theta_{\text {wilt }}, \theta_{f c}, \theta_{s}$ are soil water content at wilting point, field capacity and saturation, respectively.

The runoff from a grid cell to the local schematic stream reach is the sum of saturation excess overland flow $\left(q_{\circ f}\right)$ and groundwater discharge $\left(q_{b}\right)$ per unit length of contour line:

$q_{o f}(i, t)=\left\{S_{u z}(i, t)-S D(i, t)\right\}$

where, $S_{u z}$ is the unsaturated zone storage and $S D$ is the saturation deficit for the $i^{\text {th }}$ grid cell at time $t$.

$q_{b}(i, t)=T_{0}(i) \exp \left(\frac{-S D(i, t)}{m(k)}\right) \tan \beta_{i}$ where, $S D$ indicates the saturation deficit, $T_{0}$ is the transmissivity, and $m(k)$ is the discharge decay factor in sub basin $k$.

In flow routing calculation using the Muskingum Cunge method, the river cross section is assumed to be rectangular and river width $B$ (meters) is approximated by:

$B(i)=C \sqrt{A(i)}$

where, constant $C=10$ and $A$ is the drainage area in square kilometers (Lu et al., 1989).

The equivalent Manning's roughness coefficient of a grid cell is estimated as;

$n_{i}=n_{0}(k)\left[\tan \beta_{i} / \tan \beta_{0}(k)\right]^{1 / 3}$

where, $n_{0}$ and $\tan \beta_{0}$ are the equivalent roughness coefficient and slope at the outlet of sub-catchment $k$, respectively and $n_{0}$ is a model parameter to be calibrated.

The generated overland flow and groundwater flow of each cell will be added to the stream and then routed to the basin outlet. The maximum root zone storage is calculated considering the distribution of land cover and rooting depth. The spatial variation of soil transmissivity $\left(T_{0}\right)$ over the catchment is considered based on the percentage of sand, silt, and clay present in each soil type.

In the BTOPMC, spatially distributed monthly average potential evapotranspiration is calculated using the Shuttleworth-Wallace (S-W) method (Shuttleworth and Wallace, 1985). In the S-W method, the evapotranspiration and the energy terms are related to:

$\lambda E T=C_{c} E T_{c}+C_{s} E T_{s}$

where, for the daily simulation, ET is the evapotranspiration (mm day $\left.{ }^{-1}\right), \lambda$ is the latent heat of water evaporation ( $\mathrm{MJ} \mathrm{kg-1}), E T_{\mathcal{C}}$ and $E T_{S}$ are terms similar to the transpiration and the evaporation by applying the Penman Monteith (P-M) equation to closed canopy and bare substrate, respectively, $C_{\mathcal{C}}$ and $C_{S}$ are weighting coefficients as functions of resistances.

This article does not include a detailed description of the model and further references can be proposed as Ishidaira et al (2000) and Takeuchi et al (1999 and 2008). 
Table 1 - Basic data required to run YHyM/BTOPMC and sources of data

\begin{tabular}{|c|c|}
\hline Data Set & Source \\
\hline Digital Elevation Map (DEM) & $\begin{array}{l}\text { Shuttle Radar Topography Mission } \\
\text { (SRTM) }\end{array}$ \\
\hline Soil Map & $\begin{array}{l}\text { Harmonized World Soil Database (HWSD) } \\
\text { V } 1.1 \text { by Food and Agricultural Organization } \\
\text { (FAO) }\end{array}$ \\
\hline Land Cover dataset & $\begin{array}{l}\text { United States Geological Survey - International } \\
\text { Geosphere Biosphere Programme (USGS - } \\
\text { IGBP) Global Land Cover Characteristics Data } \\
\text { Base Version } 2.0\end{array}$ \\
\hline $\begin{array}{l}\text { Data for Shuttleworth and Wallace (S-W) } \\
\text { Simulation; } \\
\text { - Normalized Difference Vegetation Index } \\
\text { (NDVI) }\end{array}$ & $\left\{\begin{array}{l}\text { Advanced Very High Resolution Radiometer- } \\
\text { Global Inventory Modeling and Mapping Studies } \\
\text { (AVHRR-GIMMS) }\end{array}\right.$ \\
\hline 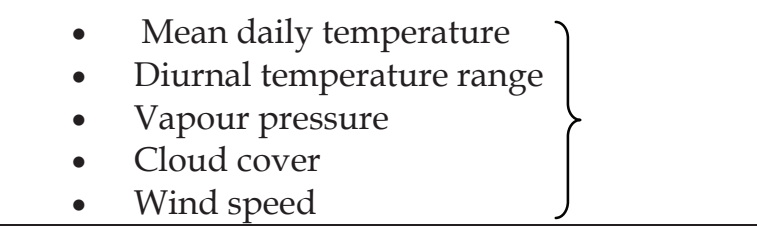 & $\begin{array}{l}\text { Intergovernmental Panel on Climate Change - } \\
\text { Climate Research Unit (IPCC-CRU) } 2.0\end{array}$ \\
\hline $\begin{array}{l}\text { Daily Discharge Data (From } 1997 \text { to 2006) at } \\
\text { Tawalama and Agaliya gauging stations }\end{array}$ & Department of Irrigation, Sri Lanka \\
\hline $\begin{array}{l}\text { Daily Rainfall Data (From } 1997 \text { to 2006) at } \\
\text { Anninkanda, Natagala, Pallegama, Baddegama, } \\
\text { Labuduwa and Galle gauging stations }\end{array}$ & Department of Meteorology, Sri Lanka \\
\hline
\end{tabular}

\subsection{Data Sets}

Table 1 shows the basic data required to run the model and sources of data. Except rainfall and discharge, all the other inputs to the model were obtained from global data sets readily available in public domain.

\section{DEM Data}

DEM data was extracted from the SRTM data set which was having spatial resolution of 3" x 3" (Jarvis et al., 2008). Due to computational limitations, it was scaled up to $30^{\prime \prime} \times 30^{\prime \prime}$ when input to the model. While inputting to the model, this scaled-up DEM data was further compared with the DEM generated using the local available contour data of 1: 50,000 scale. Input of the scaled-up DEM data (from SRTM data set) to the model performed better in generating the stream network than the local available data and hence used as the topography data in this study. Figure 3 shows the stream network generated by the model using SRTM data set.

\section{Discharge Data}

Daily Discharge Data were obtained from the Department of Irrigation, Sri Lanka for the two

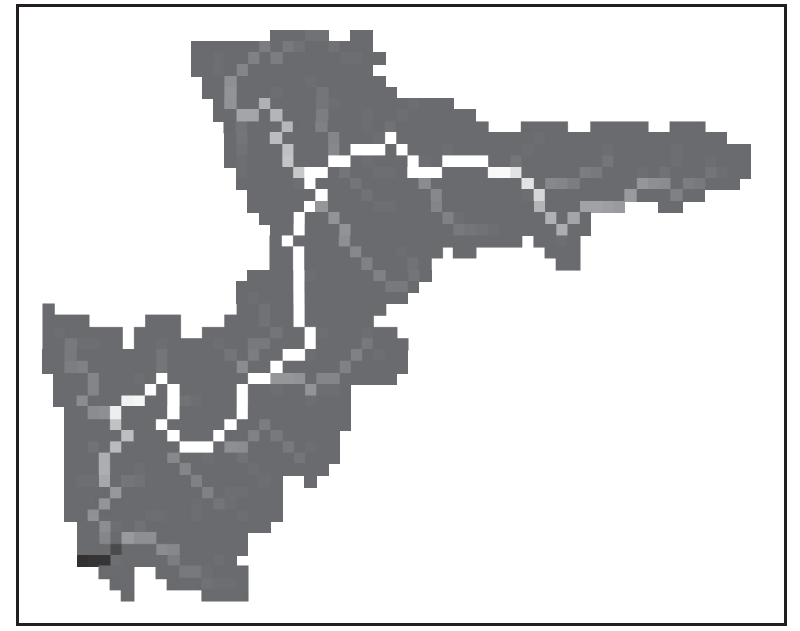

Figure 3 - Stream network generated by the model

discharge gauging stations located in Gin watershed (Figure 4). Agaliya station was established in lower reaches while Tawalama station was located in upper reaches of the catchment. The basin delineation was done based on the locations of discharge gauging stations. The whole catchment was divided to three sub catchments based on that (Figure 5). The total land areas of the upstream zone above 
Agaliya and Tawalama stations are $780 \mathrm{~km}^{2}$ and $470 \mathrm{~km}^{2}$, respectively.

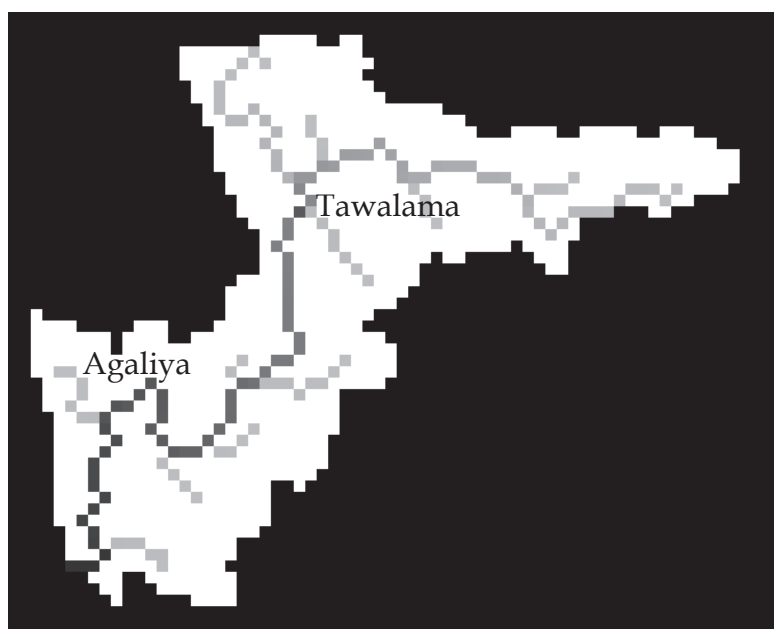

Figure 4 - Locations of discharge gauging stations

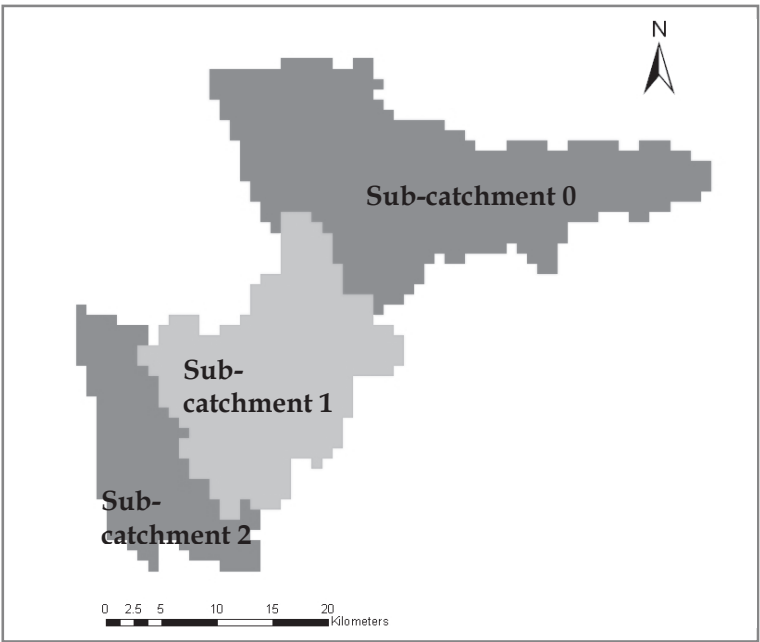

Figure 5 - Catchment sub-divisions

\section{Rainfall Data}

Six rain gauging stations were selected within the watershed and nearby locations considering the availability of long-term data. Daily rainfall data were obtained from the Department of Meteorology, Sri Lanka. Rainfall data were checked for missing data and it was noted that missing of few data, which could not be recorded during certain days. Since there existed a significant variation in the normal rainfall data of the above stations, according to Das (2009), the normal ratio method was applied to estimate the missing data. Spatial distribution of rainfall data was done by the model by using the Thession polygon method (Figure 6).

\section{Soil Data}

Soil map (Figure 7) was extracted from HWSD V1.1 produced by FAO which was having a resolution of 30" x 30" (FAO/ IIASA/ISRIC/ ISSCAS/JRC, 2009). Related soil properties and soil textures (Table 2) were identified in accordance with USDA soil triangle (Rawls et al., 1982 and 1985).

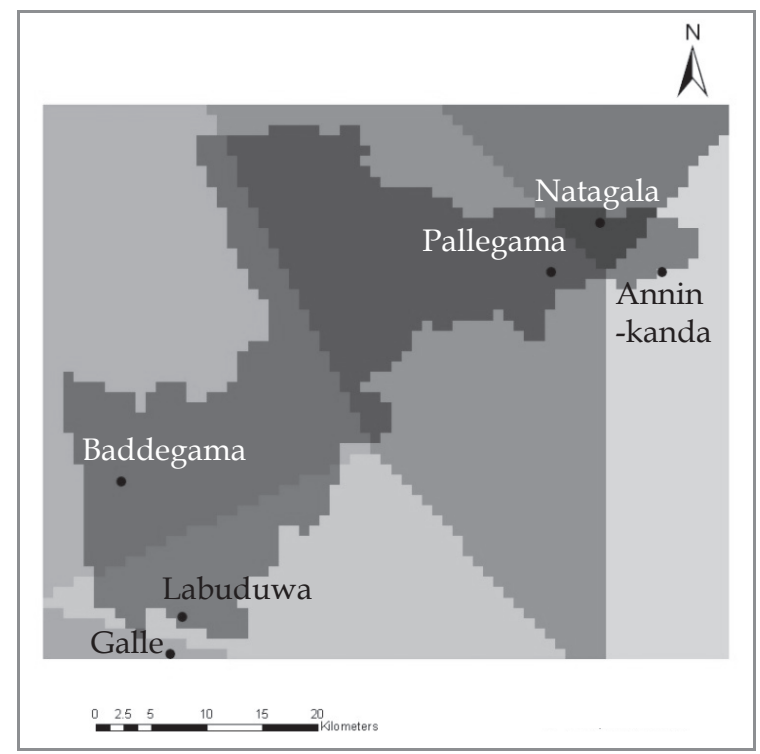

Figure 6 - Locations of the rain gauging stations and the Thession polygons generated

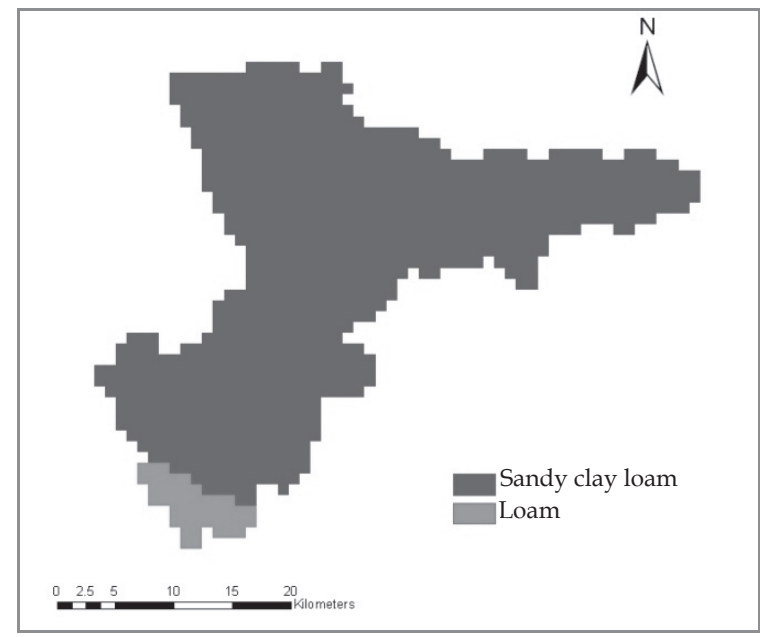

Figure 7 - Soil map (sub-catchment 0 and subcatchment 1)

\section{Land Cover Data}

30" x 30" resolution IGBP V 2.0 (From April 1992 to March 1993) developed by USGS was used for land cover classification (USGS, 2008). Seven IGBP land cover classes presented in the area were reclassified to three classes based 
Table 2 - Soil properties and distribution of soil textures

\begin{tabular}{|l|l|c|c|c|c|}
\hline \multicolumn{1}{|c|}{ Soil ID/ Soil type } & Texture & $\theta_{f c}$ & $\theta_{\text {wilt }}$ & \multicolumn{2}{|c|}{ (\% area) } \\
\cline { 1 - 3 } & & & & $\begin{array}{c}\text { Sub- } \\
\text { catchment 0 }\end{array}$ & $\begin{array}{c}\text { Sub-catchment } 0 \\
\text { and } \\
\text { sub-catchment } 1\end{array}$ \\
\hline FAO ID_3641 & $\begin{array}{l}\text { Sandy Clay } \\
\text { Loam }\end{array}$ & 0.255 & 0.068 & 100.0 & 95.44 \\
\cline { 1 - 4 } & FAO ID_3645 & & & & \\
\hline FAO ID_3778 & Loam & 0.270 & 0.027 & 0 & 4.56 \\
\hline
\end{tabular}

Notes: $\theta_{f c}$ : Field capacity, $\theta_{\text {will: }}$ Soil moisture content at wilting point

Table 3 - Distribution of land cover according to IGBP classification and root depths

\begin{tabular}{|c|c|c|c|c|}
\hline \multirow[t]{2}{*}{ Original IGBP classification } & \multirow{2}{*}{$\begin{array}{c}\text { Root } \\
\text { depth } \\
\text { (m) }\end{array}$} & \multirow{2}{*}{$\begin{array}{c}\text { Reclassified IGBP } \\
\text { classes }\end{array}$} & \multicolumn{2}{|c|}{$\%$ area } \\
\hline & & & $\begin{array}{c}\text { Sub- } \\
\text { catchment } 0\end{array}$ & $\begin{array}{l}\text { Sub-catchment } 0 \\
\text { and } \\
\text { sub-catchment } 1\end{array}$ \\
\hline Evergreen Broadleaf Forest & 2.5 & \multirow{3}{*}{$\begin{array}{l}\text { Deep rooted } \\
\text { Forest/Woodland }\end{array}$} & \multirow[t]{3}{*}{1.21} & \multirow[t]{3}{*}{1.97} \\
\hline Deciduous Broadleaf Forest & 2.5 & & & \\
\hline Mixed Forest & 2.0 & & & \\
\hline Closed Shrublands & 1.0 & \multirow[t]{2}{*}{$\mathrm{G} / \mathrm{S} / \mathrm{B} / \mathrm{S}$} & \multirow[t]{2}{*}{6.57} & \multirow[t]{2}{*}{6.11} \\
\hline Woody Savannas & 1.0 & & & \\
\hline Croplands & 0.7 & \multirow[t]{2}{*}{$\mathrm{C} / \mathrm{M}$} & \multirow[t]{2}{*}{92.21} & \multirow[t]{2}{*}{91.92} \\
\hline $\begin{array}{l}\text { Cropland/Natural } \\
\text { Vegetation Mosaic }\end{array}$ & 1.0 & & & \\
\hline
\end{tabular}

Notes: G/S/B/S: Grass/Savanna/Barren/Shrub, C/M: Crop/Mosaic

on the hydrological view point (Figure 8 and Table 3). Also the root depths for the land cover data (Sellers et al., 1994 and 1996) are shown in Table 3.

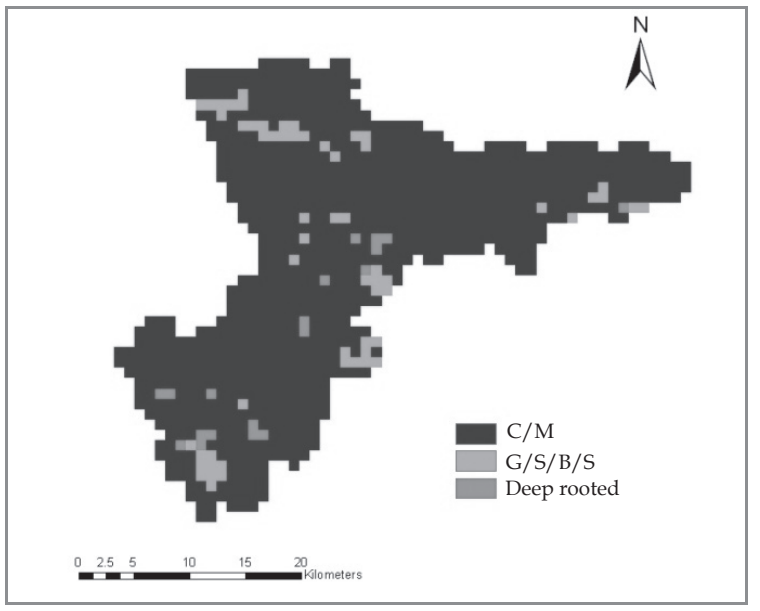

Figure 8 - Land cover map (sub-catchment 0 and sub-catchment 1)

Data for Shuttleworth and Wallace (S-W) Simulation

$0.5^{0} \times 0.5^{0}$ resolution, mean monthly climatology for 1961 - 1990 (30 year mean of the IPCC-CRU data) was used for the S-W potential evapotranspiration simulation in the YHyM/BTOPMC. These data included mean daily temperature, diurnal temperature range, vapor pressure, cloud cover and wind speed. Also extraterrestrial radiation and daylight duration were derived from the above data by using the YHyM/BTOPMC Preprocessors. NDVI data used for S-W potential evapotranspiration module included monthly data from 1981 to 2006 with 4' x 4' resolution (Tucker et al., 2005).

\subsection{Model Application}

Most of the parameters to be identified in the model are related to physical basin features of land cover and soil. Parameters have been determined manually using the model parameter identification sub-module. Decay factor of transmissivity $(m)$, Block average roughness coefficient $\left(n_{0}\right)$, Saturated transmissivity $\left(T_{0}\right)$ were identified through trial and error calibration while the maximum storage capacities at root zone were presumed based on literature values.

The effects of the actual soil properties of each grid cell are included by the $T_{0}$ value which is assigned to each grid cell based on the following equation;

$$
\begin{aligned}
T_{0}= & U_{\text {clay }} \times T_{0 \_ \text {clay }}+U_{\text {sand }} \times T_{0 \_ \text {sand }} \\
& +U_{\text {silt }} \times T_{0 \_ \text {silt }}
\end{aligned}
$$


where, $U_{\text {clay }}, U_{\text {sand }}$ and $U_{\text {silt }}$ are the percentages of clay, sand, and silt present in each grid. It is assumed that the soil texture inside each grid cell is homogeneous (Hapuarachchi et al., 2004a).

The maximum storage capacity of the root zone $\left(S_{r z} \max \right)$ is assigned to each grid cell based on the soil properties and the root depths according to the land cover maps (Hapuarachchi et al., 2004b).

$S_{r z \max }=\left(\theta_{f c}-\theta_{\text {wilt }}\right) \times$ Root depth

where, $\theta_{f c}(\mathrm{~m} / \mathrm{m})$ is the field capacity and $\theta_{\text {wilt }}(\mathrm{m} / \mathrm{m})$ is the moisture content at wilting point of the top soil layer in each grid. Soil properties in the Table 2 and root depths in the Table 3 were used for the $S_{r z} \max$ calculations.

Model performance was further improved by fine-tuning the parameter values. The calibrated parameter set used by the YHyM/BTOPMC is shown in Table 4.

Table 4 - Calibrated parameter set

\begin{tabular}{|c|c|}
\hline Parameter & Value \\
\hline $\begin{array}{l}\text { Decay factor of } \\
\text { transmissivity (m) }\end{array}$ & $0.067 \mathrm{~m}$ \\
\hline $\begin{array}{l}\text { Block average } \\
\text { roughness } \\
\text { coefficient }\left(\mathrm{n}_{0}\right)\end{array}$ & 0.4 \\
\hline $\begin{array}{l}\text { Saturated } \\
\text { transmissivity }\left(\mathrm{T}_{0}\right)\end{array}$ & $\begin{array}{ll}\mathrm{T}_{0 \_ \text {sand: }} & 12 \mathrm{~m}^{2} / \mathrm{h} \\
\mathrm{T}_{0 \_ \text {silt: }} \quad 5 \mathrm{~m}^{2} / \mathrm{h} \\
\mathrm{T}_{0 \_ \text {clay: }} \quad 1 \mathrm{~m}^{2} / \mathrm{h}\end{array}$ \\
\hline
\end{tabular}

Daily Discharge Data from 1997 to 2001 and from 2002 to 2006 were used for calibrating and validating the model, respectively. Model performance was evaluated by the NashSutcliffe Efficiency $(E)$ and the volume ratio of total simulated discharge to total observed discharge $(V r)$.

$$
E=1-\frac{\sum_{i=1}^{n}\left(Q_{o b s_{i}}-Q_{\text {sim }_{i}}\right)^{2}}{\sum_{i=1}^{n}\left(Q_{o b s_{i}}-\overline{Q_{o b s}}\right)^{2}}
$$

where, $Q_{a b s}$ is the observed discharge, $Q_{s t m_{t}}$ is the simulated discharge, $\overline{Q_{a b s}}$ is the average observed discharge, and $n$ is the number of time step.

$$
V_{r}=\frac{\sum_{i=1}^{n} Q_{s i m}}{\sum_{i=1}^{n} Q_{o b s}}
$$

where, $Q_{\text {sim }}$ is simulated runoff volume and $Q_{o b s}$ is observed runoff volume.

\section{Results and Discussion}

Table 5 shows the model performance during calibration and validation. Nash-Sutcliffe efficiencies in both calibration and validation at Agaliya (located downstream with $780 \mathrm{~km}^{2}$ drainage area) are better than Tawalama (located upstream with $470 \mathrm{~km}^{2}$ drainage area). Nash-Sutcliffe efficiency increases with the effective drainage area and this is further supported by Nawarathna et al (2001).

Figure 9 shows the observed and simulated discharge hydrographs during calibration and validation in Tawalama and Agaliya. According to Figure 9, the hydrographs show a good agreement between the observed and simulated discharges in Agaliya during both calibration and validation except for few extreme events. In particular, the low flows are simulated very well. Except for few years during which the simulated peaks are similar to the observed ones, most of the peak flows are underestimated. The reliability of the simulation results depends also upon the availability and quality of the input data. The deviation of simulated discharge from the observed is believed to be due to the overall error in the catchment rainfall estimation and uncertainty associated with the river discharge observations during peak flows. Catchment rainfall varies with altitude with mean annual rainfall above $3500 \mathrm{~mm}$ in the upper reaches, 2500-3500 $\mathrm{mm}$ in the middle reaches and less than $2500 \mathrm{~mm}$ in the lower reaches of the catchment. Most of the rain gauging stations lie in the upper and the lower reaches of the

Table 5 - Model performance

\begin{tabular}{|l|l|l|l|l|}
\cline { 2 - 5 } \multicolumn{1}{c|}{} & \multicolumn{2}{c|}{ Calibration } & \multicolumn{2}{c|}{ Validation } \\
\cline { 2 - 5 } \multicolumn{1}{c|}{} & Agaliya & Tawalama & Agaliya & Tawalama \\
\hline Nash-Sutcliffe efficiency $(E) \%$ & 67.63 & 53.75 & 62.73 & 48.31 \\
\hline $\begin{array}{l}\text { Ratio of total simulated discharge to } \\
\text { total observed discharge }(V r) \%\end{array}$ & 93.15 & 105.50 & 84.94 & 104.24 \\
\hline
\end{tabular}



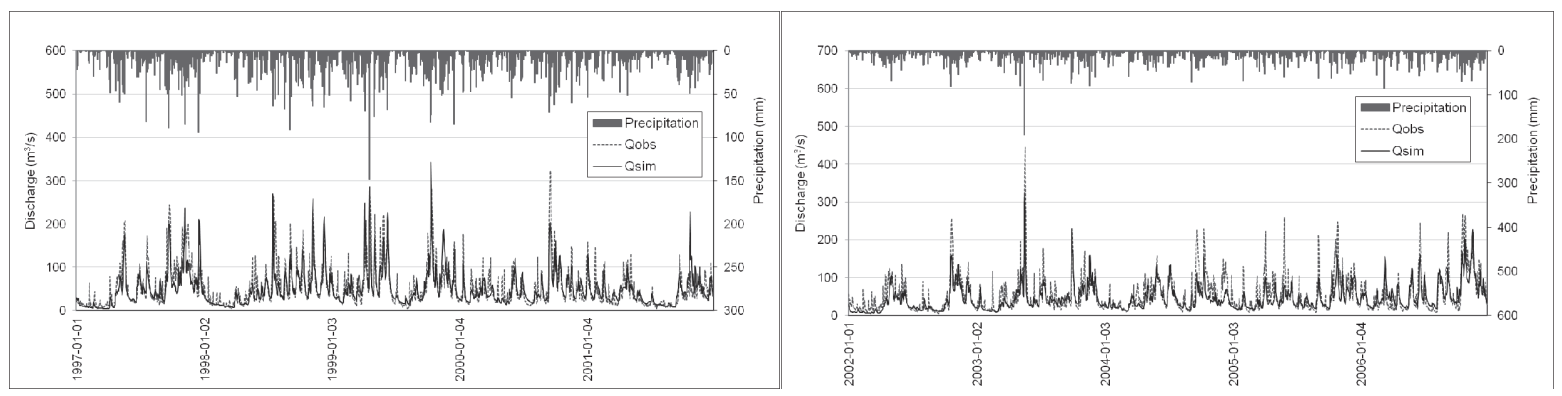

(b)

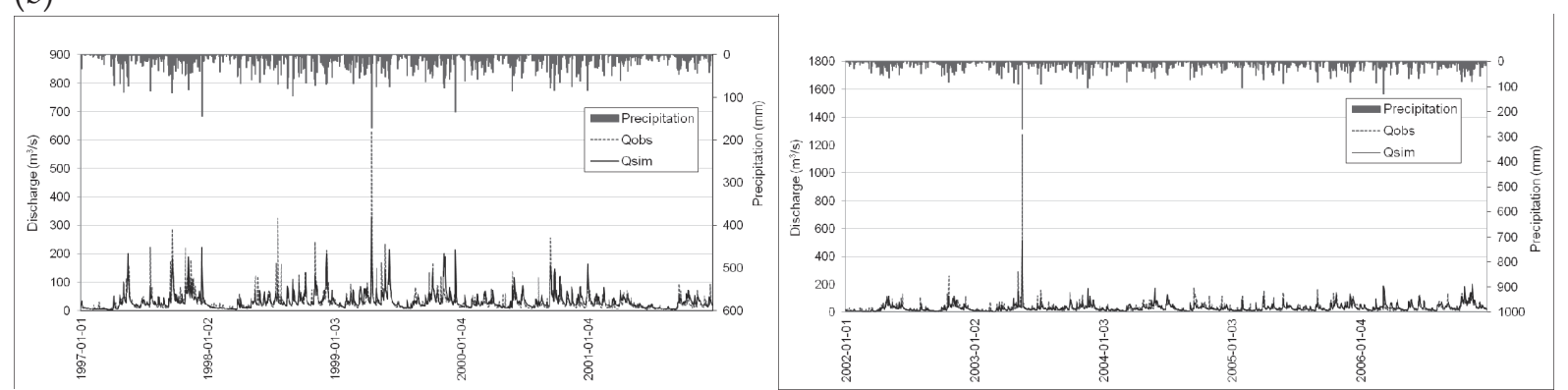

Figure 9 - Observed and simulated discharge hydrographs

Qobs is the observed discharge and Qsim is the simulated discharge during calibration and validation in (a) Tawalama and (b) Agaliya

catchment. Rainfall estimations in the middle reaches are based on the approximations using the nearest stations. This leads to formation of large Thiessen polygons in the middle reaches of the basin (Figure 6) in resulting less accurate rainfall estimations. The main storm runoff generation process considered by the YHyM/BTOPMC is surface runoff due to saturation excess overland flow. Hence the peak flow estimations during the monsoon seasons with high rainfall intensities might have been affected due to the lack of ability of the model to incorporate the infiltration excess runoff mechanism.

The model validation results at Agaliya during 2002-2006 are shown in Figure 10 for which the Nash-Sutcliffe efficiency is $62.73 \%$ and volume ratio is $84.94 \%$ (Table 5). According to Figure 10(b), in response to the rainfall, base flow shows rather direct action due to the sandy textured soils present in substantial area of the catchment. Considering Figure 10(a) and Figure 10(d), it can be shown how the model output simulates variation of the soil moisture condition of the catchment. Just after a dry season, with the start of rainfall [shown by rising limbs of the hydrographs in Figure 10(a)], $S D$ begins to decrease from its maximum. With the continuation of rainfall, $S_{r z}$ is increasing and $S_{u z}$ also begins to increase. During a peak flow event, both $S_{r z}$ and $S_{u z}$ achieve their maximum values. At the end of the peak flow event, with the decrease of rainfall, $S_{u z}$ decreases with a gradual increase of $S D$. When $S_{u z}$ achieves its minimum, $S_{r z}$ begins to decrease and $S D$ further increases. $E T$ is considered to occur from the root zone according to the EP and the availability of water in the root zone. The variation of ET [Figure 10(c)] follows the pattern of $S_{r z}$ change [Figure 10(d)] in accord with the fact that the evaporation takes place basically from the root zone. When there is enough rainfall, ET reaches nearly to its potential value which is $E P$.

\section{Conclusions}

According to the results, YHyM/BTOPMC model simulation adequately represented the major hydrological characteristics in Gin ganga watershed including runoff volume, base flow and soil moisture states of the catchment. The study utilized the global data sets readily available in public domain along with the local available rainfall and discharge data as input to the model. This suggests the applicability of YHyM/BTOPMC model for hydrologic simulations in data-poor (limited availability of local data) watersheds for which most of the required datasets could be acquired from global archives. 
(a)

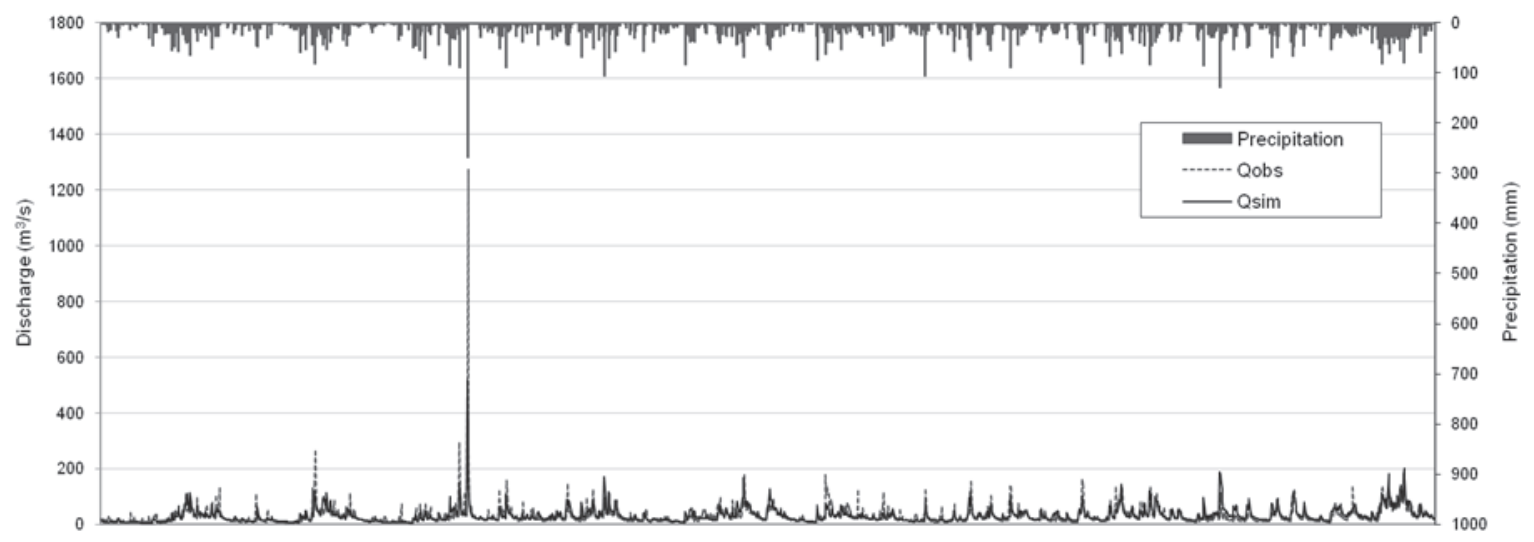

(b)

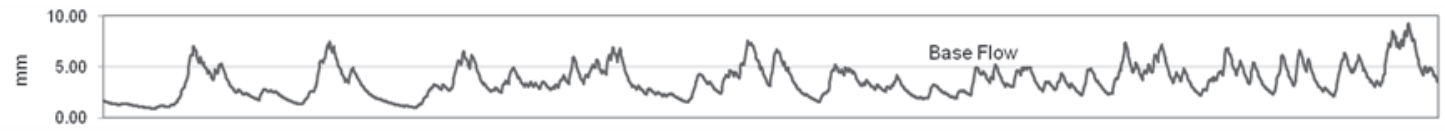

(c)

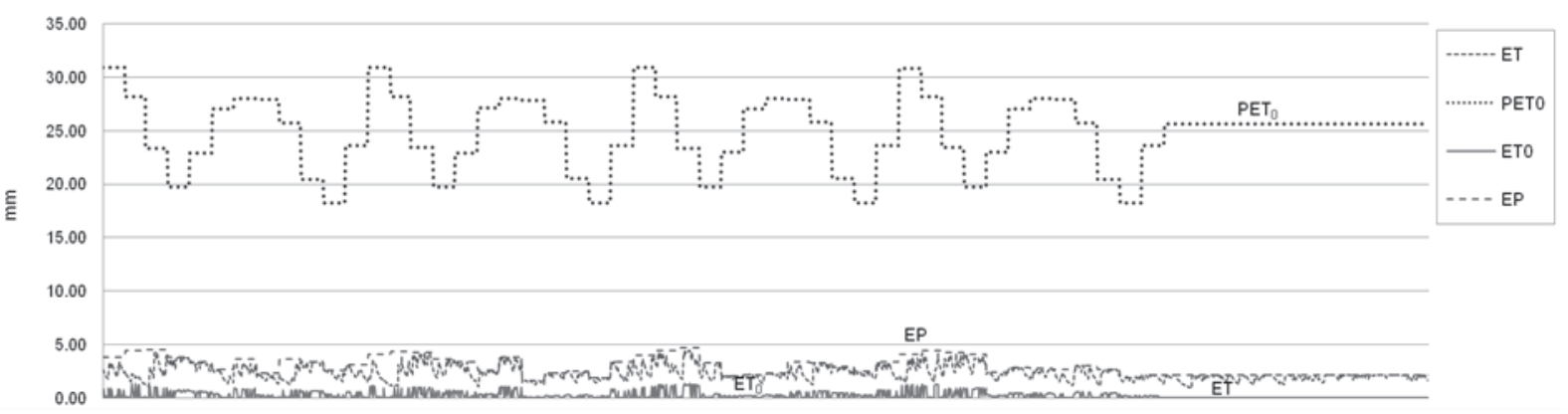

(d)

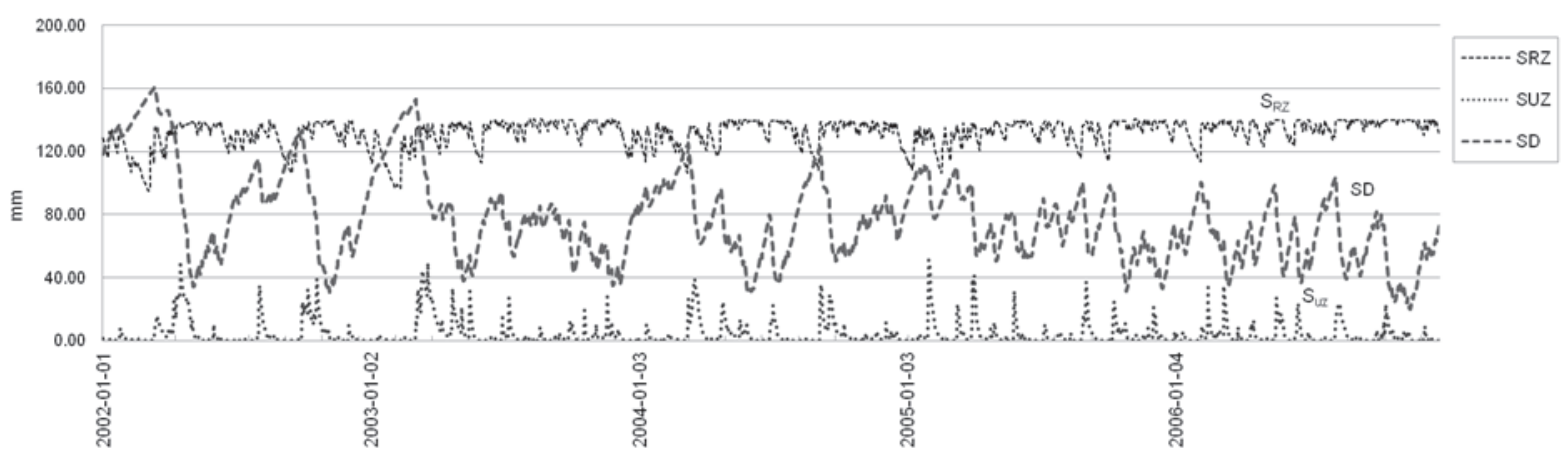

Figure 10 - Model validation results at Agaliya discharge gauging station during 2002-2006.

(a) Observed (Qobs) and simulated discharge (Qsim) hydrographs; (b) estimated base flow; (c) estimated average evapotranspiration ( $P E T_{0}$ is the potential evaporation from interception, $E P$ is potential evapotranspiration from root zone, $E T_{0}$ is the actual evaporation from interception and, $E T$ is the actual evapotranspiration from root zone); (d) Variation of estimated soil moisture (SD is the average saturation deficit, $S_{r z}$ is the average storage in the root zone and $S_{u z}$ is the average storage in unsaturated zone)

\section{Acknowledgements}

The authors gratefully acknowledge the Virtual Academy, GCOE (Global Centre of Excellence) Program, University of Yamanashi, Japan and JSPS (Japan Society for Promotion of Science) for providing necessary support for the study including the financial support. Sincere thanks are extended to Dr GHAC Silva for his guidance in making this study a success.

\section{References}

1. Ao, T., 2001. Development of a Distributed Hydrological Model for large River Catchments and its Application to Southeast Asian Rivers. Ph.D. Thesis, Department of Civil and Environmental Engineering, University of Yamanashi.

2. Ao TQ, Yoshitani J, Takeuchi K, Fukami K, Mutsura T, Ishidaira H. 2003a. Effects of SubBasin Scale on Runoff Simulation in Distributed Hydrological Model: BTOPMC. 
In Weather Radar Information and Distributed Hydrological Modeling. Tachikawa Y, Vieux BE, Georgakakos KP, Nakakita E (eds). IAHS Publ. no. 282: 227-234.

3. Ao TQ, Takeuchi T, Ishidaira H, Yoshitani J, Fukami K, Matsuura T. 2003b. Development and Application of a New Algorithm for Automated Pits Removal for Grid DEMs. Hydrological Sciences Journal 48(6): 985-997.

4. Beven K.J., Kirkby M.J., 1979. A Physically Based, Variable Contributing Area Model of Hydrology. Hydrological Sciences Bulletin. 24(1): 43-69.

5. Cunge J.A., 1969. On the Subject of a Flood Propagation Computation Method (Muskingum method). Journal of Hydraulic Researches 7(2): 205-230.

6. Das G. 2009. Hydrology and Soil Conservation Engineering. Second Edition, PHI. pp12-13.

7. FAO/IIASA/ISRIC/ISSCAS/JRC. 2009. Harmonized World Soil Database (version 1.1). FAO, Rome, Italy and IIASA, Laxenburg, Austria.

8. Hapuarachchi H.A.P., Kiem A.S., Ishidaira H, Magome J, Takeuchi K. 2004a. Eliminating Uncertainty Associated with Classifying Soil Types in Distributed Hydrologic Modeling. Proceedings of 2nd APHWConference, Singapore.

9. Hapuarachchi H.A.P., Kiem A.S., Takeuchi K, Ao T, Magome J, Zhou M. 2004b. Applicability of the BTOPMC Model for Predictions in Ungauged Basins. Proceedings of International Conference Sustainable Water Resources Management in Changing Environment of Monsoon Region, Colombo, 1719 Nov 2004.

10. Ishidaira H, Takeuchi K, Ao T. 2000. Hydrological Simulation of large River Basins in Southeast Asia. Proceedings of Fresh Perspectives on Hydrology and Water Resources in Southeast Asia and the Pacific, Christ Church, 21-24 November 2000, IHP-V Technical Document in Hydrology No. 7; 53-54.

11. Jarvis A, Reuter H.I., Nelson A, Guevara E. 2008. Hole-filled seamless SRTM data V4, International Centre for Tropical Agriculture (CIAT), available from http://srtm.csi. cgiar.org (Acquisition date 29/08/2010).

12. Lu, M.J., Koike, T., Hayakawa, N., 1989. Development of a Precipitation-Runoff Model Corresponding to Distributed Hydrological Information (in Japanese), PhD Thesis, Nagaoka University, pp. 34-35.

13. National Atlas, 2007. National Atlas, 2nd Edition, Survey Department of Sri Lanka.
14. Nawaratne N.M.N.S.B., Ao T, Kazama S, Sawamoto M, Takeuchi K. 2001. Influence of Human Activities on the BTOPMC Model Runoff Simulations in Large-Scale Watersheds. XXIX IAHR Congress Proceedings, Theme a, 93-99.

15. Rawls W.J., Brakensiek D.L., Saxton K.E., 1982. Estimation of Soil Water Properties. Transactions of ASAE 25(5): 1316-1320.

16. Rawls W.J., Brakensiek D.L., 1985. Prediction of Soil Water Properties for Hydrologic Modeling. In: Watershed Management in the Eighties, Jones EB (ed). ASCE; 293-299.

17. Sellers P.J., Tucker P.J., Collatz G.J., Los SO, Justice CO, Dazlich DA, Randall DA. 1994. A global 1 degree by 1 degree NDVI data set for climate studies. Part 2: The Generation of Global Fields of Terrestrial Biophysical Parameters from NDVI. International Journal of Remote Sensing 15(17): 3519-3546.

18. Sellers P.J., Los S.O., Tucker C.J., Iustice C.O., Dazlich D.A., Collatz G.J., Randall D.A., 1996. A Revised Land Surface Parameterization (SiB2) for Atmospheric GCMs. Part II: The Generation of Global Fields of Terrestrial Biophysical Parameters from Satellite Data. Journal of Climate 9: 706-737.

19. Shuttleworth W.J., Wallace J.S., 1985. Evaporation from Sparse Crops - An Energy Combination Theory. Quarterly Journal of the Royal Meteorological Society 111: 839-855.

20. Takeuchi K, Ao T, Ishidaira H. 1999. Introduction of Block-Wise use of TOPMODEL and Muskingum-Cunge Method for the Hydroenvironmental Simulation of a large Ungauged Basin. Hydrological Sciences Journal. 44: 4.633 - 646.

21. Takeuchi K, Hapuarachchi P, Zhou M, Ishidaira H, Magome J. 2008. A BTOP Model to Extend TOPMODEL for Distributed Hydrological Simulation of large Basins. Hydrological Processes. 22, 3236-3251.

22. Tucker C.J., Pinzon J.E., Brown M.E., Slayback D, Pak EW, Mahoney R, Vermote E, Saleous NE. 2005. An Extended AVHRR 8-km NDVI Data Set Compatible with MODIS and SPOT Vegetation NDVI Data. International Journal of Remote Sensing, Vol 26:20, pp 4485-5598.

23. USGS, 2008. United States Geological Survey International Geosphere Biosphere Programme (USGS - IGBP) Global Land Cover Characteristics Data Base Version 2.0. Available from http://edc2.usgs.gov/glcc/ta bgeo _globe.php (Acquisition date 02/09/ 2010).

24. Virtual Academy, 2010. http://www.coe.yam anashi.ac.jp/ (Acquisition date 02/09/ 2010). 